\title{
State Policies and Industrialisation in Delhi: 1921- 1951.
}

\author{
Ankur Shukla \\ Research Scholar (PhD), Department of History and Culture, Jamia Millia Islamia, NewDelhi, India.
}

\begin{abstract}
The essay here intends to enhance the understanding regarding the character of industrialization taking place during first half of twentieth century and how it led to the emergence of new industrial towns (in my study example of Delhi). My effort is to unravel the British Government's bias towards the European capitalists and the restrictions it applied to thwart the growth of indigenous industries by adopting the policy of 'Free-trade'. It was the limited but significant opportunities provided by new developments such as 'Britain's wartime needs' and 'the protective measures adopted for indigenous industries to secure these needs' along with the effects of 'Great Depression' and also the political uncertainty caused by national movement that allowed the capitalist class of these newly emerging industrial towns, to grab a chance to grow.
\end{abstract}

Key Words:- Capital Structure, Discriminating Protection, Factories, Industrialisation, Tariffs.

The British impact on Indian economy has always remained the focal point of studies on colonial Indian economic history. Bagchi has highlighted the negative impact of colonial rule over Indian Economy in his book Private Investment in India by citing some evidential data i.e. Curzon's estimate of the income per head of an average subject of British India at Rs. 39.5 or about $£ 2.13$ s. 0 d. per year in 1895 compared to Great Britain's income of $£ 52$ per year for the same. ${ }^{1}$ Daniel and Alice Thorner find the rate of growth of real national income per head being extremely low if not negative in their own study. ${ }^{2}$ The story becomes more interesting when we recall that Indian economy remained backward during whole nineteenth and major part of twentieth century in spite of being one of the colonies that experienced the growth of modern industry as early as the middle of the nineteenth century. So it becomes crucial to analyze the factors responsible for this backwardness of Indian economy especially on the sphere of industrial growth during the second half of twentieth century.

A major factor influencing the course of the secondary sector of the economy was "the attitude of the government and the operational content of its policies towards industry. 3 A change in the course was noticed right from the time of First World War when British Government made a shift in its stance by offering limited support to indigenous industries instead of following earlier regime of "free trade". It was in 1923, Government of India chose to shift towards the 'policy of discriminating protection', which not only marked the end of free trade policy followed by Britain till the outbreak of First World War but also opened the way for the growth of local industries under tariff protection. ${ }^{4}$

The history of large-scale private factory enterprise between 1850 and the First World War is associated almost entirely with developments in three industries- jute, cotton, and iron and steel. ${ }^{5}$ Before the First World War Indian exports consisted of raw materials and food grains and simple manufacturing commodities such as jute goods, cotton yarn and coarse cotton piece-goods and plantation products such as tea. ${ }^{6}$ Significant growth was achieved since the outbreak of the First World War. In the five year period from 189697 to $1900-01,63$ per cent of the country's cotton piece-goods were imported and only 10 per cent made in Indian mills, whereas in the period 1920-21 to 1924-25 only 33 per cent was imported, and 38 per cent was produced in Indian mills. ${ }^{7}$ It was only during the inter-war years that the Indian industrial structure began to diversify. Average daily employment in large-scale factories increased nearly five-fold between 1900 and 1947 , reaching at 2.65 million with 30 per cent of both output and factory employment being supplied by the textile industry. ${ }^{8}$

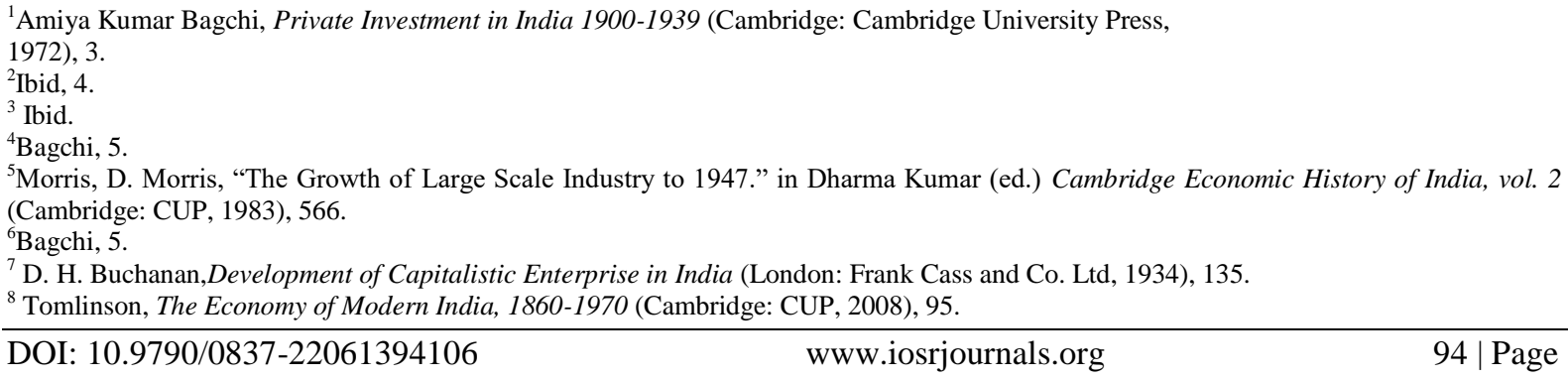


The foundations of the modern cotton textile industry were laid in western India at the same time as the jute industry was established in Bengal. But whereas the jute industry was dominated by the foreigners, the cotton industry was essentially Indian in origin, largely controlled by Indian investors, and increasingly administered by native managers and unlike the jute industry, its expansion, although certainly assisted by substantial opportunities in foreign trade, ultimately depended on its domestic markets. ${ }^{9}$ For cotton industry, Bombay acted as the core centre whereas other centres such as Kanpur and Delhi followed the patterns set by it. In case of the jute industry, the same role was played by Calcutta. One regressive aspect common in case of both the industries was their dependence on imports of machinery from abroad, primarily from U.K. ${ }^{10}$ Most of the cotton mills in India, at least before the First World War, mainly relied on producing yarn and exporting major part of it overseas, primarily to China. Since cotton manufacturing accounted for more than 36 per cent of the total imports of commodities into India between 1900-01 and 1913-14, and since cotton mills and handlooms together supplied only about 34 per cent of the total domestic consumption of piece-goods in 1900-01, there was enormous scope for substitution of imports by domestic production. ${ }^{11}$

The factors that have primarily influenced the course of potential investment in cotton-mill industry of India were the scope to replace Lancashire dominated cloth industry, successful tackling of Chinese and Japanese competition in yarn exports towards China and securing enough supply to local demands of yarn coming primarily from local handloom weavers. ${ }^{12}$ But the advantage Lancashire possessed till 1923 due to the absence of any protective mechanism for local industries of India, made the task of survival in the world and domestic market for Indian mills more difficult. Lancashire mills spun much finer count of yarn than their Indian counterparts and which ultimately enabled them to produce finer varieties of cloth. Indian mills had trouble producing finer-count yarn, mainly because domestic cotton was unsuitable. As late as 1918-19, only 2.6 per cent of their total output was 31 s count or above. ${ }^{13}$ The challenge for Indian mills was not only to produce same quality of yarn but also to overcome the prejudices against the quality of their products. It was the differential advantage in labour costs which gave Indian Industry an edge over Lancashire in the production of coarser varieties of yarn and cloth. ${ }^{14}$ So once assured with certain level of competitive edge through protection by the British government, Indian mills had the ability to produce fine yarn by exporting Egyptian cotton of longer staple.

In order to cover the state policies and their impact over industries it becomes important to study the impact of import tariffs or subsidies provided by the government. Up to the First World War, government's main emphasis was to balance the budget; ${ }^{15}$ therefore it adopted a tariff policy along a uniform basis covering all articles of import equally by applying uniform rates for the tariff and excise duties. In a situation where investment not even guaranteed marginal returns considering the underdeveloped status of Indian Industries, tariff protection becomes the final and most essential measure to be desired. British government did realize this need even during the time of First World War when it raised the general tariff rates from 5 per cent to 7.5 per cent ad valorem and the duty on imported sugar to 10 per cent along with bringing most of the import export trade under taxation system including the general tariff of 7.5 per cent on cotton piece-goods in $1917-18 .{ }^{16}$ But it came more as a reaction to the financial needs imposed by First Word War and then carried onto the post-war period.

Right from the start of the First World War there was a continuous attempt on the part of the government to check its worsening financial health through increasing tariff duties and tax rates. In 1921, the Government of India came up with an enormous deficit of 19 crores and had to turn to customs tariff for additional revenue. ${ }^{17}$ The general rate was increased from 7.5 per cent to 11 per cent and the duty on cotton piece-goods also increased to same level of 11 per cent along with a 2 per cent import duty on textile machinery, which till then was completely exempted. ${ }^{18}$ The Fiscal Autonomy convention of 1919 opened a new epoch in the tariff history of this country. According to this convention: ${ }^{19}$

The secretary of state is as far as possible to avoid interference in all cases relating to the fiscal policy of India in which the government of India and its legislature are in agreement and his intervention when it does

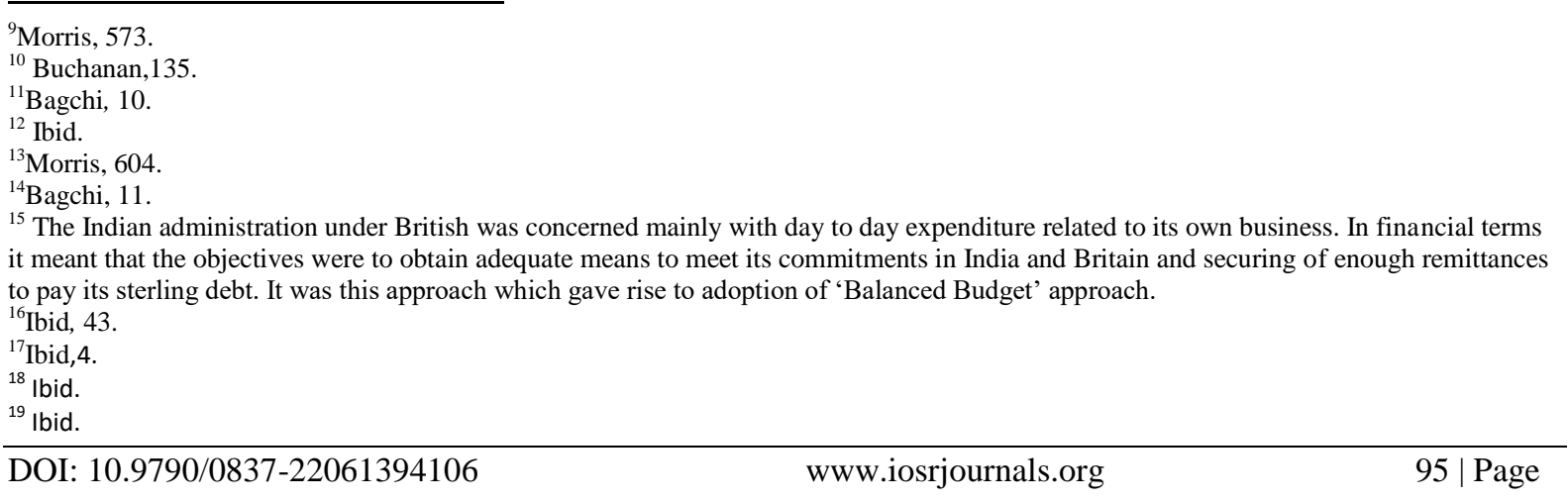


take place, is to be limited to safeguarding the international obligations of the Empire or any fiscal arrangements within the Empire to which His Majesty's government is a party.

This was followed by a policy of discriminating protection recommended by Indian Fiscal Commission (March 1921). This policy, through a resolution passed in legislative assembly on 16 February 1923 recommended that "great discrimination was to be exercised in the selection of industries for protection, so as to make the inevitable burden on the consumer as light as was compatible with the due development of industries." 20 The Commission laid down three eligibility criteria for an industry to be given protection: ${ }^{21}$

(1) It must be possessing natural advantages, such as an abundant supply of raw material, cheap power, a sufficient supply of labor and a large home market.

(2) It must also be one which without the help of protection either is not likely to develop, at all or is not likely to develop so rapidly as is desirable in the interests of the country; and

(3) Finally, it must be proved that the industry will eventually be able to face world competition without protection.

A tariff board was set up to recommend industries fulfilling eligibility to qualify for protection. Then according to the recommendations made by the board, protection was extended to iron and steel industry, cotton and sericulture industry, bamboo paper industry and gold thread industry. Before First World War the progress India made in industries such as cotton textile, jute, tea was dominated by British managing agencies. The First World War arrived for the Indian economy as a blessing in disguise as there was ample amount of opportunity available for import substitution. To the manufacturer it meant, as in cotton and coal, a cessation of foreign competition or, as in jute, manganese and other minerals useful for munitions purposes, the creation of a special demand. ${ }^{22}$ War had generated enough demand for Indian products enabling most of the large industries operating in India garner huge amount ofprofits. Soon Indian mills became the largest suppliers of piece-goods for the domestic market and maintained the status throughout the inter-war period and enjoyed as much as two third of the total market share by late 1930s. ${ }^{23}$ The jute industry of Calcutta, the cotton mills of Bombay along with few other centres such as Delhi and Kanpur made unexpected profits from this sudden drop in imports from U.K.

The Indian government signed two pacts in 1931 and 1934 with Britain and Japan respectively. Before 1932, only iron and steel and cotton piece-goods had adopted differential duties for protection, according to their British and non-British origin. The principle of Imperial Preference was first introduced in 1932 as part of the Ottawa Trade agreement, signed among, others by India and Britain. ${ }^{24}$ Under the terms of Ottawa Agreement it was agreed that a 10 per cent preference would be granted to the United Kingdom in respect of such articles made of cotton, silk or artificial silk in exchange for the preferences granted by Britain in respect of Indian exports. ${ }^{25}$ In the same year another path-breaking agreement was signed between British Textile Mission to India and the Millowners' Association, Bombay. The British delegation was headed by Sir William Clare Lees and Sir Homi Mody represented Indian Millowners' Association, therefore pact signed was known as "Mody Lee Pact". ${ }^{26}$ Under the pact both the parties agreed Indian cotton textile industry is entitled to a reasonable level of protection against the imports of UK's yarn and piecegoods. ${ }^{27}$ This step was in complete contrast to the hostile approach adopted by the British previously. Not only the British delegation agreed for higher level of protection against the countries other than Britain but also conceded small reduction in the duty on yarn imported from the United Kingdom. ${ }^{28}$ British side also agreed to promote and popularise the use of Indian origin cotton oversees. On 12 July 1934 another trade agreement was signed between India and Japan, which imposed a definite quantitative limitation on Japanese imports in order to put an effective check on Japanese Dumping. ${ }^{29}$ It was agreed that the: ${ }^{30}$

Duties on Japanese piece-goods should not exceed 50 per cent or 5.25 annas per lb., whichever was higher, in the case of plain grey goods and 50 per cent in the case of others, in return India reducing the ad valorem duty on non-British piece-goods from 75 per cent to 50 per cent and the minimum specific duty from 6 and $3 / 4$ annas per lb. to 5.25 annas per lb., with effect from $8^{\text {th }}$ January, 1934.

Paper industry had been granted protection from 1925 onwards and sugar industry secured protection in 1932. This protection soon attracted new entrepreneurship towards these industries and within half a decade

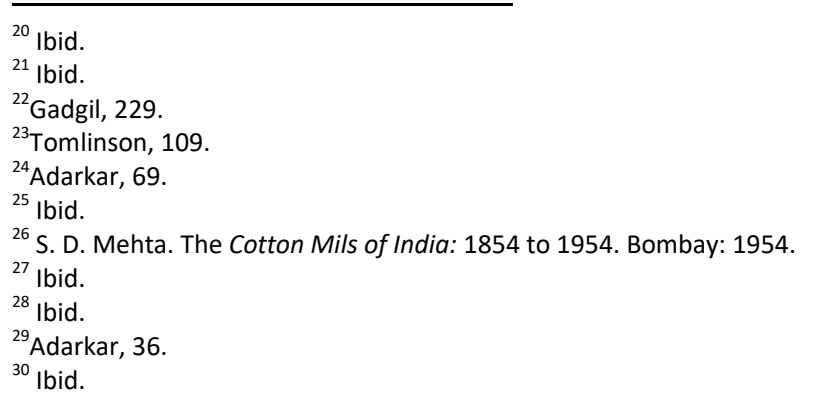


these industries achieved the level of full import substitution, crediting some part of this achievement also to improved varieties of raw materials. Now we will look at some of the crucial changes made in the monetary policy of the British government.

Before the war the external value of rupee was geared to that of sterling, and was maintained by the sale of so called Council-drafts ${ }^{31}$ and Reverse councils ${ }^{32}$. From October 1924 onwards the value of Indian rupee was kept at1s.6d. Sterling. This value of rupee received the statutory embodiment in 1926 on the recommendations of Royal Commission on Indian currency and Finance (the Hilton Young Commission). ${ }^{33}$ The principal argument given by the government in favor of the higher rate of exchange was that the rupee had naturally settled to this level. ${ }^{34}$ But evidence suggested that the level came only by government action and that a rate of 1 shilling 4 pence could have been secured safely. ${ }^{35}$ A point which reflected in the dissent made by the Indian businessmen under the representation of Sir Purushottamdas, whose principal demand was that the exchange value should be kept at pre-war levels of $1 \mathrm{~s}$. $4 \mathrm{~d}$. which might have protected local interests over foreign imports. ${ }^{36}$ The only reason acceptable was the government's difficulty, ever since the War, in balancing the Indian budget (a considerable part of which was paid out in Britain in "Home Charges"). ${ }^{37}$ The high-valued rupee enabled the finance member to pay with one eighth less rupees. ${ }^{38}$

The shift from the commercial to the financial (and strategic) aspects of British Imperial interests in India during the Inter-War period produced a profound uncertainty on the part of policy-makers with regard to the role of the government in the economy. ${ }^{39}$ According to Ray it was the fiscal deficit that drove the excise duties more and more towards the level of 15 per cent ad valorem in 1922. One negative outcome of this policy was that it kept the share of Indian investment low within the total capital employed in India. It was found that around $£ 23$ Reverse Councils sold in the process of shoring up the rupee and which went mainly into the pockets of bankers and merchant princess. ${ }^{40}$ Paul Baran also suggested that about 10 per cent of India's gross national product was transferred to Britain each year in the early decades of the twentieth century, and reminded further that had this sum been invested in South Asia, 'India's economic development to date would have borne little similarity to the actual somber record. ${ }^{41}$ Appreciation not only discouraged local investment but also lead Foreign Profits to be repatriated instead of being reinvested in the economy (there were signs of huge reinvestment made by Europeans of their profit esp. before First World War).

But signs of improvement were visible from 1933-34 onwards as the terms of trade shifted in favor of Industries. This spurt received further impetus from the outbreak of the Second World War. The value of the contracts placed by the supply department from 1939-40 to 1942-43 was of $£ 108$ millions, of which more than 80 per cent was absorbed by engineering and textile industries.In the absence of proper war planning, manufacturers in India could not take advantage of the new demand which sprang up with the outbreak of the Second World War and then whatever assets India made through the stepped up exports were left un-utilized in the absence of a long term expansion of heavy industries. Moreover there were efforts made by entrepreneurs like Shri Ram and G. D. Birla by introducing plants for the production of textile machinery, and sewing machines respectively but they were pushed back by the Government when it took over these plants for the production of munitions. This halted the manufacturing of these new products in spite of having a huge demand generated by the fall in imports. It was again Britain's war-time needs that Indian Industries had to compromise with and in return British government kept discouraging Indian efforts. As evidence we have example of Walchand's efforts while asking for government's aid in setting up an Aircraft Factory which government refused to assist. ${ }^{42}$ The Government may have justified its stance in the name of ensuring maximum efficiency of war production on a world-wide basis but the cost that had to be paid by Indian economy was quite huge and probably answers the question that why till the end of Second World War Indian Economy was kept limited to the role of the suppliers of raw materials and munitions. Now we will discuss the performance and growth of textiles industry during inter-war years under the tariff policy.

\footnotetext{
${ }^{31}$ Council Drafts (bills) were sold by secretary of state in London to facilitate remittances to India and to defray the expenditure incurred by the government of India through the India office.

32 When there was a fall in exchange value of rupees situation was met by the sale of Bills in India known as Reverse Councils to be cashed in Gold or Sterling in London.

${ }^{33}$ Bagchi, 64.

${ }^{34}$ Buchanan, 476.

35 Ibid.

${ }^{36}$ Bagchi, 64.

${ }^{37}$ Buchanan, 476.

${ }^{38}$ Ibid.

${ }^{39}$ Rajat Ray, 239.

${ }^{40}$ Ibid.

${ }^{41}$ Tomlinson, 20.

${ }^{42}$ Progress of Joint Stock Companies in India. Ministry of Finance, Department of Company Law Administration: New Delhi, $1955,4$.

DOI: 10.9790/0837-22061394106 $\quad$ www.iosrjournals.org |Page
}




\section{PROTECTION TO TEXTILE INDUSTRY}

The cotton textile industry was the backbone of the Indian industrial economy and thus maintained a special claim to protection on the ground of its national importance, whether as measured by the number of people supported by it or as evidenced by the fact that it acquired the 20.3 per cent of the total industrial capital in 1913-14. ${ }^{43}$ After seeing a War pressed boom from 1919 to 1922 the cotton textile industry in India was caught in a wave of depression caused by reduced demand and the growing severity of competition from Japan. In a note written at the time of budget discussions in 1930 the Commerce Member estimated that approximately 12.5 per cent of the imports of cotton piece-goods from the U.K., 90 per cent of the imports from Japan, and 40 per cent of those of other countries, competed directly with Indian goods. ${ }^{44}$ The fall in cloth prices began in 1921; the exchange had already reached its lowest point and the largest price-fall came about in the year 1921-22. ${ }^{45}$ This led to a strong demand from the local cotton manufacturers to repeal the already levied duty of 11 per cent on cotton piece-good and 5 per cent on cotton yarn. The duties which were seen as more of a remunerative source of revenue were continued for 3 more years despite receiving strong political resentment. But finally this pressure from the local manufacturers compelled the government to suspend the duty in 1925 and finally to be abolished in $1926 .^{46}$

The Indian Tariff (Cotton yarn amendment) Act of 1927 was the next installment of assistance granted to the textile industry. ${ }^{47}$ According to the views of Board the reason behind the current crisis was the unfair advantage enjoyed by Japan in terms of applying double shift and the deployment of women and children during night time, which was a clear violation of the Washington Labor Convention. ${ }^{48}$ The cost difference Japan realized over Indian mills was of 10 percent as a result of such measures. ${ }^{49}$ In order to address the grievances of local cotton manufacturers, government admitted of a need to protect locally spun yarn but refused to provide it in the form of an import duty as for them it may have left a repercussion on handloom weavers, who himself depended on the availability of cheaper foreign yarn. Thus the government decided to remove the duties on mill stores and textile machinery as immediate relief. But as the measure proved ineffective, the government decided to replace the duty of 5 per cent ad valorem on cotton yarn with an alternative duty of 5 per cent or 1.5 annas per lb., whichever was higher and to balance out the added pressure on handloom industry it reduced the duty on artificial silk yarn from 15 to 7.5 per cent $^{50}$, but the move proved ineffective in front of severe Japanese competition.

Government of India was again forced to consider the question of protection to cotton textiles industry in 1929 and appointed Mr. G. S. Hardy as special officer to examine and report the necessary steps to be taken as a cure. ${ }^{51} \mathrm{Mr}$. Hardy in his report mentioned that categories of grey and coloured goods were under severe threat and thus need to be dealt with ad valorem duties in place of specific duties. This protection was granted in 1930. The revenue duty which had been 11 per cent since 1925 was increased to 15 per cent on British goods and to 20 per cent on non-British goods. ${ }^{52}$ This step was justified on the ground that as the Indian industry had grown of late years chiefly at the expense of the British industry even with an 11 per cent duty, a duty of 15 per cent would provide adequate protection to the Indian industry against the competition of Lancashire; while against Japanese competition it was necessary to provide a higher protective wall. ${ }^{53}$ It was also decided to prescribe a specific duty of 3.5 annas per $1 \mathrm{~b}$. on plain grey goods and an additional duty of 5 per cent ad valorem on other medium varieties of imported goods. The thing to be noted here is that finer varieties of cloth in which Britain possessed clear cut advantage, were left untouched. These proposals were embodied in the Cotton Industry (Protection) Act, 1930, which was passed on $4^{\text {th }}$ April 1930 and stayed valid for a period of three years. $^{54}$

The duty on cotton piece-goods was further enhanced by The Finance Act of 1931 which imposed a surcharge of 5 per cent, so that the ad valorem duties on British and non-British piece-goods were raised to 20 and 25 per cent, respectively. ${ }^{55}$ The Supplementary Finance Act of 1931, imposed a surcharge of 25 per cent which raised the duty on British piece-goods to 25 per cent and that on non-British piece-goods to 31.25 per cent., and the minimum specific duty on plain grey goods from 3.5 annas to 4 and 3/8 annas per lb. ${ }^{56}$ As a result

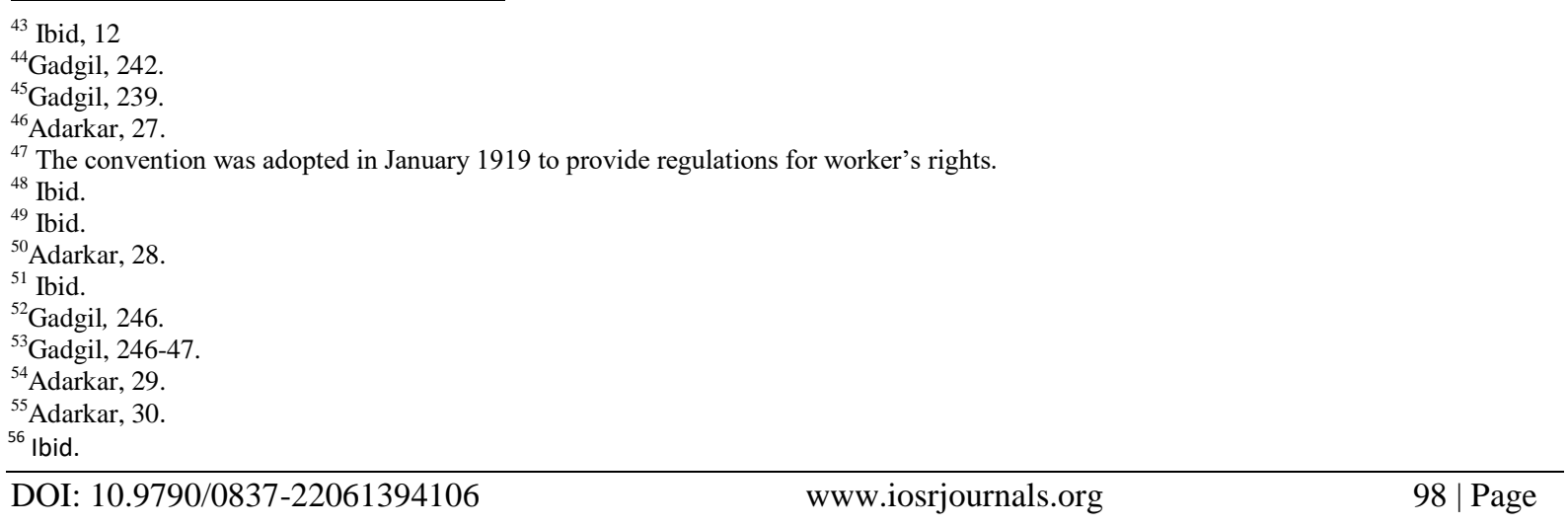


of the same surcharge the duty on cotton yarn was increased from 5 per cent to 6.25 per cent. The duty on artificial silk yarn was raised by the Finance Act of 1931 to 15 per cent in addition to the surcharge of 25 per cent. ${ }^{57}$ But even this proved insufficient as Japanese imports continued to increase. ${ }^{58}$ Another appeal was made to Government and the Tariff Board of 1932 was asked to report on the question. Government decided to provide more relief by increasing the ad valorem duty to 50 per cent, and the minimum specific duty on plain grey goods from 4 and 7/8 annas to 5.25 annas per $\mathrm{lb}^{59}$ Keeping in mind the significant growth achieved by Indian textile industry in the decades of 1930's more so specifically in grey and bleached cloth market with a major share of the home market, the board estimated that the measure of protection required for each class of cloth was as follows: ${ }^{60}$

5 annas a pound for plain grey, 5.25 annas for bordered grey, 6 annas for bleached and 6 and 1/3 annas for colored goods. These duties were to be applied for both British and Non-British goods. Board also highlighted the earlier flaws in Hardy's recommendations in his report for not covering fine cloth under protection along with choosing ad valorem duties for protection which reduced the measure of protection in a period of falling prices. ${ }^{61}$ Among their supplementary recommendations, the board proposed the continuance of the duty on raw cotton in the interest of the cultivator of cotton. These recommendations were implemented under The Cotton Textile Industry Protection (Amendment) Act, 1933.In the year 1933 an agreement was signed between India and Britain known as The Bombay Lancashire Pact according to which it was agreed that: ${ }^{62}$

In the matter of cotton yarn the duties against yarn of British origin might be reduced from 6.25 per cent or 1 and $7 / 8$ annas per $\mathrm{lb}$. to 5 per cent or 1.25 annas per $\mathrm{lb}$., while so as far as artificial silk piece-good is concerned, the following duties were considered adequate in the case of imports from the United Kingdom: 30 per cent ad valorem or 2.5 annas/square yard for 100 per cent, artificial silk fabrics (in place of 50 per cent ad valorem or 4 annas/square yard) and 30 per cent or 2 annas/square yard for mixture fabrics of cotton and artificial silk (in place of 35 per cent or 2.25 annas/square yard).

In return for these concessions British Textile Mission, who represented Britain in this pact, agreed to do everything in power to popularize and promote the use of Indian raw Cotton in the United Kingdom. The validity of the pact was to remain in effect till $31^{\text {st }}$ December $1935 .^{63}$

After reviewing the changes in the revenue and fiscal policies of the government of India one can notice that almost on every occasion the prime mover behind the changes in the policy was Government's quest for more revenue income. Key items to be often kept under the scrutiny were cotton piece-goods, sugar, liquors, tobacco, kerosene, matches and silver. Cotton piece-goods, sugar, kerosene and matches being articles of general consumption and having comparatively in-elastic demand, the duties on them were proved by experience to be good revenue producers, and comparatively stable even during the time of depression.

\section{INDUSTRIALISATION IN DELHI 1921-1951}

The district of Delhi was first constituted in 1819 and consisted of two parganas, North and south. ${ }^{64}$ From 1861 onwards the district consisted of three tehsils, viz. Delhi, Ballabgarh and Sonipat. ${ }^{65}$ On the creation of the new province in 1912 the Sonipat tahsil was transferred to the Rohtak district and the bulk of the Bullabgarh tahsil went over to the Gurgaon district. ${ }^{66}$ The entire Delhi tahsil and a portion of the Ballabgarh tahsil were included in the new province classified as Delhi province, while in 1915 Shahdara and some villages across the river were added from the Gaziabad tahsil of the Meerut district.

In the sphere of industries Delhi can rightly claim a long tradition as the home of master craftsmen in all branches of arts and crafts practiced from earliest times. Delhi as seat of power attracted skilled craftsmen in various industries and arts. But it was in colonial India that the establishment of three engineering works and iron foundries during the years 1872 to 1879 heralded the process of modern industrialization in Delhi. ${ }^{67} \mathrm{New}$ ground was broken when two cotton textile mills were set up in 1888 and 1889 in Delhi. ${ }^{68}$ The year 1893 and 1905 witnessed the inception of 2 more spinning mills and another modern engineering works was set up in $1905 .{ }^{69}$ The establishments of a modern flour mill and a biscuit factory in the 1898 were the other two

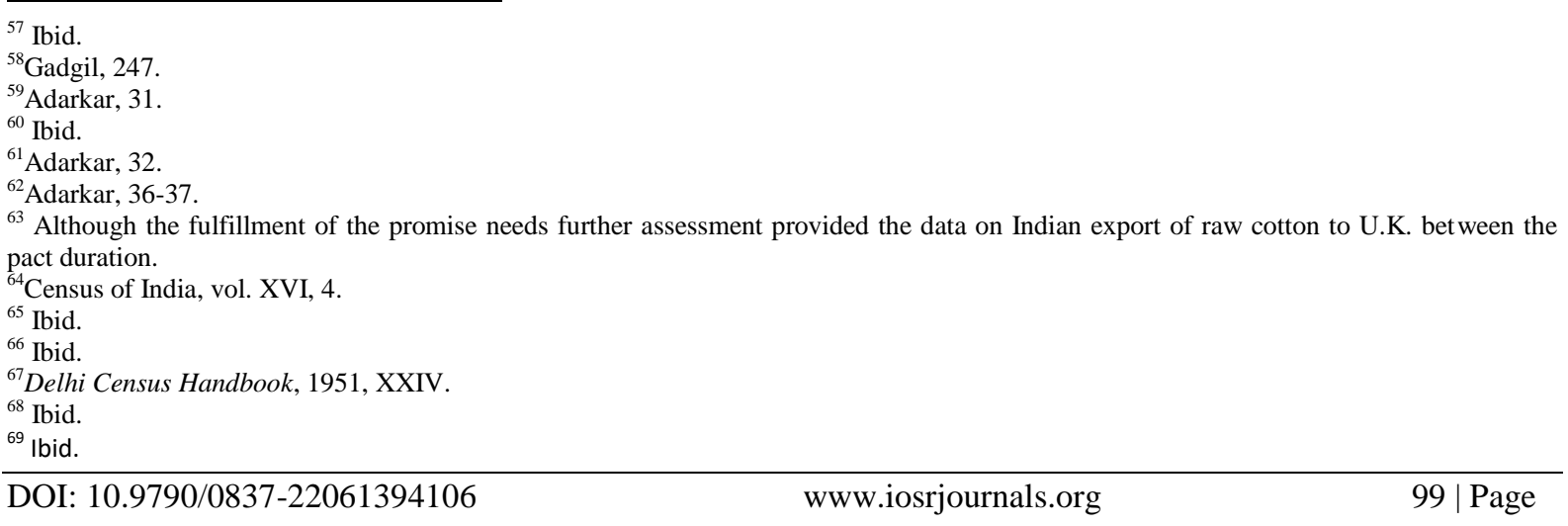


distinguished features of industrial development in Delhi during nineteenth century. More rapid industrialization was achieved with shifting of capital from Calcutta to Delhi in 1911. The cotton mill industry after experiencing several reverses secured a sound foothold by about the year 1919. Two large flour mills came into existence in 1917 and $1918 .^{70}$ The first ice factory was established in 1907 known as 'Prag Ice Factory' near Old Sabji Mandi, followed by another one in 1912.

Thus we see that at the outbreak of the First World War Delhi had already developed a strong base in terms of industrial growth. Commercial gains made during this period acted as a base for the further growth achieved during the inter-war period. It was during the inter-war period, Delhi took a giant stride on the path of industrialization with the advancement in the industries like Textile, Metal, Engineering works, Sheet metal industries, Electrical goods, Ceramics industry, Chemical industry and in the Industries of food and Drink. It was the war situation that not only created the demand for the locally manufactured goods but also presented the opportunity for import substitution after the decline in foreign imports caused by First World War.Along with the progress in these mainstream industries, significant growth was achieved in the newer industries such as hosiery, lace and braids factories, gold and silver thread and lametta industry, oil mill, flour mill, acid factory, oil paints varnishes and lacquers industry, glass ware and vegetable oil industries.

The outbreak of Second World War provided the industries of Delhi further impetus not only to consolidate its growth achieved during inter-war phase but also to embark upon newer set of opportunities created by the gradual diminution of the imports of capital goods, raw materials of industry and consumer goods from foreign countries along with the mounting requirement of the defense services for a large variety of manufactured goods of various categories. Industrial sector of the city cashed this opportunity with both hands as the number of registered factories alone more than doubled during the war years from 111 in 1939 to 227 in $1945 .^{71}$ There was a good deal of dislocation in the industrial scenes of Delhi soon after the cessation of hostilities in 1945 but on the whole majority of industries tided over the difficult period of transition from the war to peace-economy. In between industry had to face the difficulties like the government's control over the production and distribution of raw materials ${ }^{72}$, restrictions on the movement of machine tools and factory plants, labor ordinances, control of joint stock enterprises and above all the extreme shortage in the supplies of industrial fuels and restricted transport facilities for the movement of raw material and finished goods alike. Even after the partition, Delhi kept the rate of industrial growth upward as the number of registered factories stood at 431 in 1951 as against 227 in 1947 with the increase in number of workers engaged from 36,870 to 40,780 in March 1951. ${ }^{73}$

*It is to be clarified that in March, 1951 the number of registered factories stood at 431. The data provided in the

\begin{tabular}{|c|c|c|c|c|c|c|c|}
\hline \multicolumn{8}{|c|}{ Table 1} \\
\hline \multicolumn{8}{|c|}{ Delhi Industries at a Glance, 1951} \\
\hline \multirow{2}{*}{$\begin{array}{l}\text { Serial } \\
\text { No. }\end{array}$} & \multirow[t]{2}{*}{ Name of Industry } & \multirow{2}{*}{$\begin{array}{l}\text { No. of factories } \\
\text { or establishments }\end{array}$} & \multirow{2}{*}{$\begin{array}{l}\text { Capital } \\
\text { investment }\end{array}$} & \multicolumn{4}{|c|}{ No. of Workers } \\
\hline & & & & Males & Females & Children & Total \\
\hline 1 & Textile Industry & 258 & $650,86,104$ & 18,730 & 812 & 167 & 19,709 \\
\hline 2 & Engineering Works & 503 & $345,05,468$ & 7,311 & 7 & 332 & 7,604 \\
\hline 3 & Metal Industry & 402 & $27,17,700$ & 1,208 & - & 174 & 1,387 \\
\hline 4 & Sheet Metal Industry & 539 & $45,84,215$ & 2,460 & 16 & 814 & 3,280 \\
\hline 5 & Electrical Goods & 71 & $76,77,539$ & 1,176 & - & 38 & 1,214 \\
\hline 6 & Ceramics Industry & 28 & $37,46,100$ & 1,372 & 72 & 37 & 1,481 \\
\hline 7 & Chemical Industry & 111 & $105,62,916$ & 1,610 & 31 & 40 & 1,681 \\
\hline 8 & $\begin{array}{l}\text { Industries of food \& } \\
\text { Drink }\end{array}$ & 1,143 & $127,17,980$ & 4,808 & 20 & 19 & 5,047 \\
\hline 9 & Miscellaneous Industries & 323 & $168,56,000$ & 5,806 & 47 & 240 & 6,093 \\
\hline 10 & Small Scale Industries & 348 & $26,88,790$ & 1,944 & 38 & 50 & 2,032 \\
\hline & Grand Total & $3,726^{*}$ & $16,11,42,812$ & 46,425 & 1,043 & 1,911 & 49,528 \\
\hline
\end{tabular}

Table 1 includes both the registered and unregistered industrial undertakings including, establishments working on cottage scale.

As shown in Table 1, the capital investment in all these industries amounted to a little over Rs. 16 crores with textile industry, engineering works and industries of food and drink being the chief manufacturing industries. The optimum annual productive capacity of all these industries is: ${ }^{74}$ estimated at goods worth Rs. 78 crores, though their actual annual production does not exceed Rs. 31 crores which is only 40 per cent of their

\footnotetext{
${ }^{70}$ Ibid.

${ }^{71}$ Report of An Industrial Survey Conducted in 1950-51 in Delhi State, (Delhi: The Directorate of Industries and Labour Delhi State, 1952) 5.

${ }^{72}$ Ray, 254-256.

${ }^{73}$ Industrial Survey, 6.

${ }^{74}$ Ibid, 7.
} 
optimum productive capacity. Among these industries textile industry was the most advanced one with the capital share of around 40 per cent as well as the work force of 19,709 which also formed the 40 per cent of the total work force involved in the industries of Delhi at the end of March 1951. The remaining 60 per cent capacity remains idle due to either shortage of raw materials, fuel, and power or inadequate financing and marketing facilities.

Now we will discuss the growth of different industries from 1921 to 1951 :

\section{TEXTILE INDUSTRY}

The textile industry not only formed the core of manufacturing in India but it was also the most pioneering industry of Delhi. Dating its inception from the year 1888 the cotton mill industry, with an aggregate capital investment of nearly 5 crores, provided daily employment to about 15,000 operatives at the end of 1951 . The inception of the industry around Delhi had been entirely due to its central position with regard to such important consuming markets for the nearby cities in Rajasthan, Uttar Pradesh and Punjab, and the excellent rail and road communications ( branching from Delhi in all directions ) complemented this situation further. The strong rail and road network also ensured that the industry did not need to face the scarcity of raw material while being supplied from the other parts of the country in case of its nearest supplier of raw cotton Punjab failed to produce enough cotton for the mill consumption.

We have already discussed the inception of four cotton mills in quick succession from 1888 to 1911 but immediately after the beginning of the War there was a setback to the prosperity of a great many industries, e.g. cotton, coal, manganese, etc. ${ }^{75}$ During the War there was a halt in building new mills due to the stoppage in the imports of machinery. In 1921 the number of mills and spindles were actually less than in 1914, while looms were more by about 20 per cent. $^{76}$ This decline in ratio between loom and spindle was due to sudden warpressed demand which made existing companies and newer establishments to focus on the supply of mainly yarn products. Since the profits were unprecedented and the investment (of advanced power looms as well as skilled labour and engineers) necessary to initiate cloth weaving was very high, mill management kept their focus on yarn production especially during initial couple of years after the First World War. Post-War prosperity provided further impetus to growth and from 1919 onwards the existing mills started an intensive programme of all round expansion. The year witnessed the establishment of Goenka Spinning and Weaving Mills Limited at Azadpur on the Grand Trunk Road by Messrs. Paras Ram Harnand Rai with a capital investment of Rs. 10,00,000. The mill was equipped with 307 looms, and a modern dying and bleaching plant, while the addition of the spinning machinery was postponed in view of the easy availability of the cheap imported yarns.

There was also a take-over of Hanuman and Mahadeo Spinning and Weaving Mills Limited from Seth Rai Bahadur Kanhaiyyalal by Birla Brothers Limited for the price of Rs. 5,00,000. After Ghanshyamdas acquired it, it was renamed 'The Birla Cotton Spinning and Weaving Mill Limited'. In April 1920 Ghanshyamdas floated a company to formalize its take-over. Incorporated on 10 March 1920, the company's prospectus declared that the mill was to have a capacity of 13,000 spindles. Orders were placed in England for machinery and meanwhile a weaving department was started. The mill's authorized capital was Rs. 15,00,000 made up of 1,50,000 shares of Rs. 10 each. In 1920 one lakh shares of the total value of Rs. 10,00,000 were offered to the public and the share issue was fully subscribed. The directors of the company were G.D.Birla, Narsinghdas Kothari (of M/s Bagla Kothari and Co.) and Babu Ghanshyamdas Loyalka (of M/s G.D. Loyalka and Co.).

The Delhi Cloth and General Mills Company Ltd, established their mill no. II in 1925 and Mills No. III in 1928, which were equipped with capital of 20,000 spindles each and 600 and 500 looms respectively. ${ }^{77}$ The Goenka Mill which provided employment to nearly 500 men stopped working in 1927 and remained closed for a number of years. Later the Goenka Mill was purchased by Messrs. Shadi Ram and Sons in June 1943 who started working it under its new name of Ajudhia Textile Mills Ltd. with the authorized capital of Rs. $25,00,000 .^{78}$ Two power loom factories also started during the war years, and The Delhi Cloth and General Mills Limited added another mill in the line known as Swatantra Bharat Mills with the latest type machinery, and the building plans and the lay-out conforming to western standards.

\footnotetext{
${ }^{75}$ Gadgil, 229.

${ }^{76}$ Buchanan, 201.

${ }^{77}$ Industrial Survey, 11.

${ }^{78}$ Ibid, 12. 
State Policies and Industrialisation in Delhi: 1921 - 1951.

Table $2^{79}$ Cotton Mills of Delhi, 1951 March

\begin{tabular}{|c|c|c|c|c|c|}
\hline $\begin{array}{l}\text { Serial } \\
\text { No. }\end{array}$ & Name and address of the Factory & $\begin{array}{l}\text { Name of the } \\
\text { proprietor }\end{array}$ & Year of Estb. & $\begin{array}{c}\text { No. of } \\
\text { Workers } \\
\text { employed }\end{array}$ & $\begin{array}{l}\text { Private or } \\
\text { Limited } \\
\text { Concern }\end{array}$ \\
\hline 1 & $\begin{array}{l}\text { Ajudhia Textile Mills Ltd., P.O.Azad, } \\
\text { G.T.Karnal Road, Delhi }\end{array}$ & $\begin{array}{l}\text { General } \\
\text { Manager: Seth } \\
\text { ShadiLal }\end{array}$ & 1951 & 570 & $\begin{array}{l}\text { Private } \\
\text { Limited } \\
\text { Concern }\end{array}$ \\
\hline 2 & $\begin{array}{l}\text { Birla Cotton Spinning and Weaving Mills } \\
\text { Ltd., Birla Lines, Sabzimandi, Delhi }\end{array}$ & $\begin{array}{lr}\text { Mg. } & \text { Agents: } \\
\text { M/S } & \text { Birla } \\
\text { Bros. } & \text { Ltd., } \\
\text { Calcutta } & \end{array}$ & 1919 & 4600 & $\begin{array}{l}\text { Public } \\
\text { Limited } \\
\text { Concern }\end{array}$ \\
\hline 3 & $\begin{array}{l}\text { Delhi Cloth and General Mills Co. Ltd. (A, } \\
\text { B, and C mills) Bara Hindu Rao, Delhi }\end{array}$ & $\begin{array}{lr}\text { Mg. } & \text { Director: } \\
\text { Shri } & \text { Bharat } \\
\text { Ram } & \\
\end{array}$ & 1989 & 8194 & $\begin{array}{l}\text { Public } \\
\text { Limited } \\
\text { Concern }\end{array}$ \\
\hline 4 & Rama Textiles Ltd, Nicholson Road, Delhi & $\begin{array}{l}\text { Mg. Directors: } \\
\text { R.S.Khushi } \\
\text { Ram Chharia, } \\
\text { Shri Ram } \\
\text { Chandra } \\
\text { Chharia }\end{array}$ & NA & 60 & $\begin{array}{l}\text { Private } \\
\text { Limited } \\
\text { Concern }\end{array}$ \\
\hline 5 & $\begin{array}{l}\text { Shri Jain Weaving and Dyeing Factory, } \\
\text { Shidipura, Karolbagh, Delhi }\end{array}$ & $\begin{array}{l}\text { Partners: } \\
\text { ShriChajjuLal, } \\
\text { ShriRamjiLal }\end{array}$ & NA & 85 & $\begin{array}{l}\text { Private } \\
\text { Concern }\end{array}$ \\
\hline 6 & $\begin{array}{l}\text { Swatantra Bharat Mills, Nazafgarh Road, } \\
\text { P.O. New Industrial Area), New Delhi }\end{array}$ & $\begin{array}{l}\text { Proprietors: } \\
\text { The Delhi } \\
\text { Cloth and } \\
\text { General Mills } \\
\text { Ltd., Delhi }\end{array}$ & 1949 & 1806 & N.A. \\
\hline
\end{tabular}

Source: Report of An Industrial Survey Conducted in 1950-51 in Delhi State, Directorate of Industries and Labour, Delhi, 1952, 12.

At the end of March 1951 the aggregate authorized capital of all the existing 8 mills in Delhi amounted to Rs 5,30,00,000, out of which Rs. 3,31,09,430 and Rs. 41,94,865 are subscribed and paid-up capital, respectively. ${ }^{80}$ The total number of spindles and looms installed are 1, 62,593 and 2,254 respectively. ${ }^{81}$ The total number of workers employed in them is 15,333 including 138 female workers. ${ }^{82}$ The aggregate annual production during the year 1950-51 amounted to 2,75,77,059 lbs. of yarn and 8,23,22,598 yards of piece-goods, of which about 855 were grey and bleached goods and the rest coloured, besides 4,33,330 dozens of towels. ${ }^{83}$

\section{HOSIERY INDUSTRY}

This industry allied to the textile industry, made its presence felt in 1919 in the industrial world of Delhi with the establishment of first such factory of this kind. It was the limited supply of imported hosiery goods that provided the necessary impetus for the establishment of hosiery industry in Delhi and during the period 1920-25 nearly 8 new companies were set up. This period of boom in the industry peaked in 1927. These companies undertook production on a large scale of cotton, woolen, silk, tussor socks and stockings, mufflers, sweaters, jerseys, caps, ties etc. in men's and children's sizes and knitted goods for ladies' wear. During the period ending 1935 two more concerns were established in 1927 and 1930 respectively, one of which worked in Delhi up to 1936, when its plant was shifted to Gwalior and the other closed down after working for about four years. ${ }^{84}$ In between this the industry had to confront the large scale dumping of cheap hosiery products by Japan and China in particular after the initial period of boom leading to the shutdown of most of the local factories, allowing only three factories to survive this type of competition and to be able to continue their production. The aggregate capital invested in the industry at the end of March 1951 was at Rs. 20.72 lacks with the number of factories reaching 78 employing around 800 workers. $^{85}$

\section{IRON FOUNDRIES AND LARGE ENGINEERING WORKS}

In Delhi the metal industry was the second most significant industry with a work force of around 4,000 workers. As we have already discussed in the first chapter that the history of metal industry dates back to the

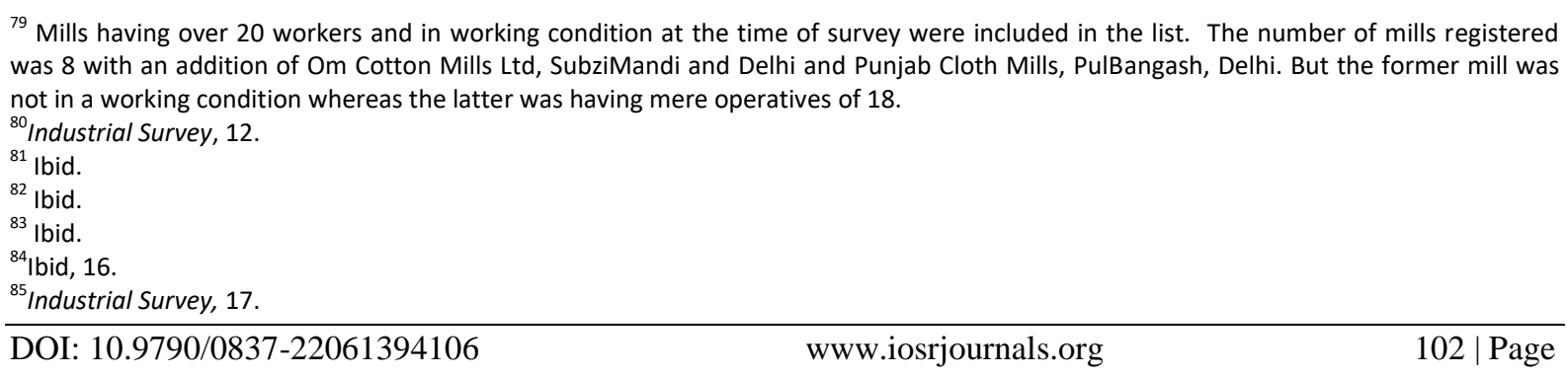


1870 's. But it was the shifting of the capital from Calcutta to Delhi, that paved the way for the growth as the enormous building plan of the New Delhi area with modern sewage and sanitary created great demands for the products like cast-iron pipes, man hole covers, sanitary fittings and under-ground electricity cable fittings with such accessories as T-joint boxes, bell type boxes, ceiling roses etc. and electric poles. Later around 1920, the demand for shifting collars and couplings, pulleys and plumbers blocks also generated.

The total number of foundries and large engineering concerns in Delhi stood at 173 at the end of March 1951. ${ }^{86}$ The total capital investment of all these concern amounted to Rs. 254.88 lacks with a work-force of around 4,000 workers (excluding cottage workers). ${ }^{87}$ Other than the goods we had earlier mentioned, some of the concerns also started the production of items required for defense services like semi-rotary pumps for high octane spirit, bomb racks cradles, parachute containers, stirrup pumps, terminal boxes, foot air pumps, set containers, petrol tanks and metallic fittings for railways. But the most prominent item of these concerns was the sugarcane crushers. During the war the production of crushers, and rollers was estimated to have increased about 50 per cent. ${ }^{88}$ Nearly 50 per cent of the crushers produced in Delhi were exported to Uttar Pradesh, 20 per cent to Punjab and 30 per cent to Rajasthan. ${ }^{89}$

\section{GOLD, SILVER THREAD AND LAMETTA INDUSTRY}

Known as the premier artistic industry in the textile section, Gold Silver Thread and Lametta industry had a well-established structure within Delhi. The area around Old Delhi was supposed to be the hub of such artist known by the local name of Karkhanda's. Lamettawas used in designer dresses for embroidering purpose. Later original gold and silver wires were replaced by artificial gold or silver coated wires. Previous to 1914 silver constituted the base for the wire, and wire drawing was done entirely by hand tools and implements. In 1914 Delhi began to change over from the production of real silver (rupehra-white) and silver coated with gold lametta to imitation lametta with copper wire as the basic metal. ${ }^{90}$ Supply of gold wire (raw material) came initially from Russia but after the outbreak of First World War it was replaced with supplies from Germany and France, both sharing the 70 per cent and 30 per cent of the export to India, respectively. It was the advancement in the prices of gold and silver with the outbreak of First World War that compelled local manufacturers to shift their production to imitation lametta (for which copper wire acted as the replacement for gold and silver wire).

Shift from real qualities towards imitation lametta lead to the emergence of Delhi as the largest centre in India for the production of such type during 1940s. The Delhi manufacturers didn't experience any serious competition from other manufacturing centres in India like Amritsar, Jaipur and Ajmer because in these areas the production was small and the quality was also inferior to that of Delhi products. Industry acquired more market space during the Second World War as the number of such concerns increased from 32 in 1938 to 47 in $1950 .^{91}$ There was also significant increase in the capital investment from the pre-war level of Rs. 5, 93,200 to Rs. 7, 07,200 in 1950 along with the increase in the number of workers employed from 745 to 805 in $1950 .{ }^{92}$

Table 3

\begin{tabular}{|l|c|c|}
\hline Class of Workers & Wages paid in 1939 (in Rs/day) & Wages paid in 1950 (In Rs./day) \\
\hline $\begin{array}{l}\text { Lametta Weaver } \\
\text { skilled }\end{array}$ & 2 & 3.5 \\
\hline Semi skilled & 1 & 1.5 \\
\hline $\begin{array}{l}\text { Dabkayya (flatner) } \\
\text { skilled }\end{array}$ & 1.5 & 2.5 \\
\hline Semi skilled & 0.75 & 1.13 \\
\hline Wire drawer skilled & 2 & 3.5 \\
\hline Semi skilled & 3 & 1.5 \\
\hline $\begin{array}{l}\text { Electroplater Head } \\
\text { man }\end{array}$ & 1.5 & 5 \\
\hline Helper & & 2 \\
\hline
\end{tabular}

Source: Industrial Survey, 26.

Power driven machinery came to be largely employed after 1929, when it got successfully imported initially from Surat and later from France and Germany. Prior to the partition of the country, of the total production of Delhi, nearly 40 per cent was consumed by Punjab, Kashmir, N.W.F.P. and Baluchistan (largely doribraids for decorating men's waistcoats and ladies bodices and kalakbatun for embroidery work on clothes and shoes), 35 per cent was exported to Rajputana states, 20 per cent to Uttar Pradesh and 5 per cent to Calcutta

\footnotetext{
${ }^{86}$ Ibid, 28.

87 Ibid.

${ }^{88}$ Industrial Survey, 29.

89 Ibid.

${ }^{90}$ Industrial Survey, 29.

${ }^{91}$ Ibid, 25.

92 Ibid.
} 
(gota and kalakbatun). ${ }^{93}$ There was a significant increase in the level of wages paid to workers in 1951 than that of given in 1939. Wages of different types of workers are given above in Table 3.

\section{THREAD BALL INDUSTRY}

The thread ball industry was one of the premier industries of Delhi. The first factory for the production of thread balls by cross winding was set up in Delhi in 1893. Prior to that a beginning was already made in Bombay for the production of ordinary cotton cards for sewing, while sewing thread in the shape of balls was imported from the United Kingdom (90 per cent) and other countries (10 per cent). ${ }^{94}$ Thread balling machines were worked in two parts, viz bobbin winder (also known as charkha) and the "baller". The first balling machine was imported in 1893from Manchester. Later it was copied in wood and hence leading to its manufacture on a commercial basis. By 1917 the number of thread ball factories had risen to 30 and the number of machines installed in them to $1500 .^{95}$ The wooden machines were, however, heavy to work and necessitated constant replacements, especially for the swivels and axles. In 1922 one of the local manufacturers substituted bicycle hubs with metal axles in place of wooden axles, and in 1932 other rotating parts were replaced by ball bearings. ${ }^{96}$ These changes resulted in the doubling of the production.

\begin{tabular}{|l|c|c|}
\hline \multicolumn{3}{|c|}{ Table 4 } \\
\hline \multicolumn{3}{|c|}{ Daily Earnings of Workers in Thread Ball Industry } \\
\hline \multicolumn{3}{|c|}{} \\
\hline Women Workers & 1939 (In Rs.) & 1950 (In Rs.) \\
\hline Male Worker & 1.25 & 3 \\
\hline Children & 2.5 & 5 \\
\hline
\end{tabular}

Source: Industrial Survey, 23.

The yarn for making thread balls, single or double and four-ply continued to be imported from the United Kingdom till 1922 when Messrs. E. D. Sasoon and Co. of Bombay started the production of gassed yarn for thread ball making. The Kohinoor Mills which entered the fields for the supply of yarn in 1930 had established itself as the leading concern both in regard to the quality and diversity of the yarn produced and their supply of products included cotton silk, mercirised, embroidery and crochet yarn to the Indian manufacturers both in Delhi and elsewhere. The industry, in 1950 had provided employment to around 579 operatives in 86 factories as compared to 860 operatives with 43 factories in $1939 .{ }^{97}$ It was estimated that in 1951 there were 3000 thread balling machines installed in the 86 establishments of Delhi. ${ }^{98}$ The total investment in the industry including machine plant at that time was estimated at Rs. $14,31,000 .{ }^{99}$ The daily earnings of the different types of workers of this industry are provided above in table 4.

\section{ELECTRIC FANS}

At the end of March 1951 there were six concerns in Delhi for the production of electric fans, of which three were involved in the production of ceiling, table and garden fans whereas other three had limited their production only to ceiling fans. The oldest concern which was established in 1941 mainly engaged in the manufacturing of fixed and oscillating table fans of 12", 14" and 16" sizes and ceiling fans of 48", 52", 56" and 60 " sweep. ${ }^{100}$ The second concern which started its production in 1944 was specialized in A/C ceiling fans besides Hamilton telegraph posts, cooking, ranges and hurricane lanterns. The aggregate capital investment of the six concerns in this line was estimated at Rs. 65, 86,689 providing employment to about 532 men. ${ }^{101}$ The monthly production of ceiling and table fans in these concern amounted to 500 and 400 respectively. ${ }^{102}$

\section{FLOUR MILLING}

\footnotetext{
${ }^{93}$ Ibid, 26.

${ }^{94}$ Ibid, 22.

${ }^{95}$ Ibid.

96 Ibid.

${ }^{97}$ Ibid, 23.

98 Ibid.

99 Ibid.

${ }^{100}$ Industrial Survey, 23.

101 Ibid.

102 Ibid.
} 
We have already talked about Delhi being one of the main trading centres for trade of Ata and wheat products like sooji, rawa and maida. Delhi Flour Mill, which was established on $17^{\text {th }}$ May 1916 with an authorized capital of Rs. 12,00,000; had their product exported to distant markets such as Calcutta and other towns in Bengal, Bihar and Uttar Pradesh. Delhi at the end of March 1951 had 3 large scale flour mills and 5 medium scale mills. Out of the eight mills two had been lying idle for over nine years due to damage in their plants, which could not be repaired due to non-availability of spare parts required for replacements. The total capital investment of these mills exceeded Rs. 47 lacks, and they provided employment to nearly 650 workers. Their aggregate monthly grinding capacity was of 3, 12,000 maunds. ${ }^{103}$ These three large mills had entered into a pool arrangement in 1924 with a view to eliminate internal competition whereby Delhi Flour Mills Company, Ltd continued grinding on behalf of the partnership, while the Ganesh and Crown Flour Mills remained totally closed. With a break for a couple of years in between, the arrangement lasted till 1940 when all three mills started working separately in order to meet the increasing demand and continued to supply their entire production to the Rationing Authorities in Delhi.

\section{VEGETABLE OIL MILLING}

Vegetable oil milling was carried out in the Delhi State in well-organized mechanically fitted factories as well as in cottage establishments with bullock driven kolhus. Of the organized factories 8 were located in Delhi, 3 in Delhi-Shahdara, one on Mathura Road, one at Narela and one at Najafgarh. ${ }^{104}$ The aggregate number of expellers and Ghanis installed in them were 4 and 168, respectively, and their monthly output averaged 12,630 maunds. ${ }^{105}$ The capital investment of these mills was estimated at Rs. 17, 75,000 and all these mills provided employment to nearly 330 persons. ${ }^{106}$ Majority of the oil produced by these mills was Kachi Ghani oil which retained the pungent odor. With very little demand locally for such type of oil most of the quantity was exported to Bengal and Bihar. Delhi imported 80 per cent of its oil seed from the Punjab and 15 per cent from Uttar Pradesh, the remaining 5 per cent of the supply coming from the produce of the state. ${ }^{107}$

\section{ICE INDUSTRY}

At the end of March 1951 there were 30 ice factories with a daily plant capacity of 676 tons of ice. ${ }^{108}$ The aggregate capital investment in the industry amounted to about Rs. 20, 08,000 with a working force of 340 operatives. ${ }^{109}$ All of these factories were equipped with condensation plants with four of them driven by steam while others were electric. Till the year 1942 the ice factories of Delhi enjoyed a flourishing export trade in their products with their market expanding to Alwar and Jaipur states, Jhansi, Beawar, Ambala and Panipat in Punjab and Meerut and Shaharanpur in the Uttar Pradesh. ${ }^{110}$ With the increase in the population of Delhi during the war years, the production of ice fell short of the demand, and eventually in 1944 the selling price of ice was controlled, and exports were totally stopped with the exception of supplies to railway restaurants and dining cars.

\section{RUBBER GOODS INDUSTRY}

In the year 1935 there were two factories established in Delhi, with one involved in the production of rubber balloons, teats and nipples, and another one in the re-treading of motor tyres. Later during the Second World War there were three more factories established for the production of moulded rubber goods. The first one established in the year 1940 was involved in the production of moulded goods such as bottle stoppers, rings and washers and shoe heels, rings for sewing machines and bicycle handle grips, brake shoes and paddle bar rubber besides ebonite sheets and battery containers. ${ }^{111}$ As for its raw materials the company had a plant installed to reclaim the rubber from old tyres and tubes of old cars and bicycles and cabs. The rubber good plant of the second concern was installed in 1942 for the supply of rubber sheets to government by a firm of large Government contractors for tentage. ${ }^{112}$ The factory was equipped with mixing machines, tubing machines, rollers, calender, press and vulcanisers. The third concern in the line was established in $1944 .{ }^{113}$ The products of the concern included rubber rings for sewing machines, gunner's ear-plugs, rubber caps for crutches, and bicycle and cab tyres. ${ }^{114}$ According to the survey conducted by the Directorate of Industries and Labor Delhi,

\footnotetext{
${ }^{103}$ Ibid, 72.

${ }^{104}$ Industrial Survey, 74.

105 Ibid.

106 Ibid.

${ }^{107}$ Ibid.

${ }^{108}$ Ibid.

${ }^{109}$ Industrial Survey, 74.

${ }^{110}$ Ibid, 79.

${ }^{111}$ Ibid, 87

${ }^{112}$ Industrial Survey, 87.

${ }^{113}$ Ibid.

${ }^{114}$ Ibid.
} 
there were 11 concerns existed of fairly large capacity engaged in the production of rubber goods and retreading and vulcanizing of motor cars tyres at the end of march 1951. The total capital investment of these concerns estimated at Rs. 6.5 lacks with an employment of around 300 workers daily.

Thus we see that there was a potential for faster growth which could have been tapped by a more adequate tariff policy on the part of the government of India. But government, with its war considerations and war-time needs, always maintained a hold back over protective measures, therefore slowing the growth of local industries. Although there were some changes in the tariff and stores purchase policy of the government of India which I have already discussed during the initial part but all proved futile due to the failure of local industries in achieving desired level of import substitution of cotton piece-goods, at least not, till the start of Second World War. If the protection to Indian industries had been granted parallel to improvement in transport, it would have provided a great stimulus to Indian manufacturing.

\section{Author \\ DECLARATION:}

I hereby declare that this paper is original and in that sense if any instance of plagiarism is found, it must be discarded. This paper has not been submitted for publication elsewhere but to your "IOSR (JHSS)" Journal only. I assure to abide by the rules of your esteemed journal.

(ANKUR SHUKLA) 